Nafta-Gaz 2019, no. 7, pp. 379-387, DOI: 10.18668/NG.2019.07.01

\title{
Potential of Helianthus annuus for phytoremediation of lead, zinc, total petroleum hydrocarbons (TPH) and polycyclic aromatic hydrocarbons (PAHs) contaminated soil
}

\author{
Potencjał Helianthus annuus w fitoremediacji gleb zanieczyszczonych: cynkiem, \\ ołowiem, substancjami ropopochodnymi (TPH) i wielopierścieniowymi węglowodorami \\ aromatycznymi (WWA)
}

\author{
Dorota Kluk, Teresa Steliga \\ Oil and Gas Institute - National Research Institute
}

\begin{abstract}
This paper describes the results regarding effectiveness of treatment of soils contaminated with heavy metals (lead, zinc), total petroleum hydrocarbons (TPH) and polycyclic aromatic hydrocarbons (PAHs): naphthalene (Nap), phenanthrene (Phe), fluoranthene (Flt), chrysene(Chr), in the process of phytoremediation carried out a laboratory scale with the plant Helianthus annuus. The reason behind the work was to investigate how plant vegetation can reduce the concentration of heavy metals in the soil and how the presence of petroleum substances and polycyclic aromatic hydrocarbons affect the efficiency of their removal. The analysis was based on the dynamics of cleaning the contaminated soils which contained periodic testing on physical, chemical and toxicological properties of: uncontaminated soil, soil contaminated with TPH and PAHs, soil contaminated with heavy metals, soil contaminated with heavy metals and petroleum substances. Phytoremediation of soils and its effectiveness in pot experiments was assessed based on physical and chemical soil analyses as well as five microbiotests applying organisms belonging to three trophic levels: producers (Phytotoxkit ${ }^{\mathrm{TM}}$ and Spirodela Duckweed Toxkit), consumers (Ostracodtoxkit ${ }^{\mathrm{TM}}$ ) and decomposers (Microtox $\left.{ }^{\circledR} \mathrm{STP}, \mathrm{MARA}\right)$. The conducted research has shown that combining the results of chemical analyzes and biological tests on contaminated soils enable a real ecotoxicological assessment of environmental hazards. Six-month long phytoremediation of soils contaminated with heavy metals ( $\mathrm{Pb}, \mathrm{Zn})$, and heavy metals together with petroleum substances (TPH, PAHs), yielded results in terms of a content reduction of: lead (from of $472-495 \mathrm{mg} / \mathrm{kg}$ dry mass of soil to $226-318 \mathrm{mg} / \mathrm{kg} \mathrm{d.m}$.), zinc (from $998-1030 \mathrm{mg} / \mathrm{kg} \mathrm{d.m}$. to $520-656 \mathrm{mg} / \mathrm{kg} \mathrm{d.m}$.), TPH (from $4806-4824 \mathrm{mg} / \mathrm{kg}$ d.m. to $2774-3180 \mathrm{mg} / \mathrm{kg} \mathrm{d.m}$.) and PAH (removal rates of Nap: at 28,0-29.9\%, Phe: at 25.1-27.0\%, Flt: at 24-26,3\%, Chr: at 14.5-18.6\%). After finishing the experiment the content of lead and zinc in the plant biomass was also measured. Based on the obtained results, conclusions were made regarding issues related to usage of phytoremediation to clean contaminated soils depending on the concentration and type of toxic substance.
\end{abstract}

Key words: soil, phytoremediation, zinc, lead, petroleum substances, TPH, PAH, toxicological tests.

STRESZCZENIE: W artykule opisano wyniki efektywności oczyszczania gleb zanieczyszczonych metalami ciężkimi (ołów, cynk), substancjami ropopochodnymi oraz wielopierścieniowymi węglowodorami aromatycznymi, takimi jak: naftalen (Nap), fenantren (Phe), fluoranten (Flt), chryzen (Chr), na drodze fitoremediacji, do której przeprowadzenia wykorzystano Helianthus annuus. Badania odbywały się w skali laboratoryjnej. Celem prowadzonych prac było zbadanie, jak wegetacja roślin może ograniczyć stężenie metali ciężkich w glebie oraz w jaki sposób obecność substancji ropopochodnych i wielopierścieniowych węglowodorów aromatycznych wpływa na efektywność ich usuwania. Analiza dynamiki oczyszczania skażonych gleb polegała na periodycznym badaniu właściwości fizycznych, chemicznych i toksykologicznych: gleby niezanieczyszczonej, gleby zanieczyszczonej substancjami ropopochodnymi TPH i WWA, gleby zanieczyszczonej metalami ciężkimi oraz gleby zanieczyszczonej metalami ciężkimi w obecności substancji ropopochodnych. Ocenę efektywności fitoremediacji gleb w eksperymentach wazonowych prowadzono na podstawie wyników analiz fizycznych i chemicznych gleb oraz pięciu mikrobiotestów zawierających organizmy należące do trzech poziomów troficznych: producentów (Phytotoxkit ${ }^{\mathrm{TM}}$ i Spirodela Duckweed Toxkit), konsumentów (Ostracodtoxkit ${ }^{\mathrm{TM}}$ ) oraz reducentów (Microtox ${ }^{\circledR}$ SPT, MARA). Wykonane badania wykazały, że połączenie wyników analiz chemicznych i testów biologicznych zanieczyszczonych gruntów umożliwia realną ekotoksykologiczną ocenę zagrożenia dla środowiska. W wyniku prowadzonego sześciomiesięcznego procesu

Corresponding author: D. Kluk; e-mail: dorota.kluk@inig.pl

Article contributed to the Editor 31.12.2018. Approved for publication 31.05.2019 r. 
fitoremediacji gleb skażonych metalami ciężkimi ( $\mathrm{Pb}, \mathrm{Zn})$ oraz metalami ciężkimi, TPH i WWA osiągnięto obniżenie zawartości: ołowiu (z zakresu 472-495 mg/kg s.m. do 226-318 mg $/ \mathrm{kg} \mathrm{s.m.),} \mathrm{cynku} \mathrm{(z} \mathrm{poziomu} \mathrm{998-1030} \mathrm{mg} / \mathrm{kg}$ s.m. do $520-656 \mathrm{mg} / \mathrm{kg} \mathrm{s.m.),} \mathrm{TPH}$ (z $4806-4824$ mg/kg s.m. do poziomu 2774-3180 mg/kg s.m.) oraz WWA (Nap: o 28,0-29,9\%, Phe: o 25,1-27,0\%, Flt: o 24-26,3\%, Chr: o 14,5-18,6\%). Po zakończeniu 6-miesięcznego procesu fitoremediacji wykonano analizę chemiczną materiału roślinnego celem określenia zawartości ołowiu i cynku. Na podstawie uzyskanych wyników przeprowadzonego eksperymentu sformułowano wnioski dotyczące zagadnień związanych z zastosowaniem fitoremediacji w procesie oczyszczania skażonych gleb w zależności od stężenia i rodzaju substancji toksycznej.

Słowa kluczowe: gleba, fitoremediacja, cynk, ołów, substancje ropopochodne, TPH, WWA, testy toksykologiczne.

The development of industrial activity favors environmental degradation connected with excessive accumulation of harmful substances such as heavy metals and hydrocarbons (Total Petroleum Hydrocarbons (TPH), Polycyclic Aromatic Hydrocarbons (PAHs)) in aquatic and soil ecosystems (Steliga and Kluk, 2017; Bielińska et al., 2018; Jacob et al., 2018). Accumulation of both hydrocarbons and heavy metals exceeding the permissible standards in the soil has negative impact on the development and vegetation of plants as well as on other living organisms present in such ecosystems (Doni et al., 2012; Khoramnejadian and Khoramnejadian, 2013; Kacprzak et al., 2014). In recent years a lot of attention has been paid to reclaim degraded areas by phytoremediation, during which natural activity of plants is used with biological, chemical, physical processes allowing removal of harmful substances from contaminated environment. The way in which phytoremediants interact with toxic substances is diverse, depending on the properties of pollutants, the plant species and the environmental conditions (e.g., type and frequency of microorganisms that inhabit the root zone of plants). There are plants that are very effective in removing toxic substances with ability to efficiently collect and integrate them into their own cells (phytoextraction), capable of active metabolism and degradation (phytodegradation), collection of contaminants, their transpiration and evaporation in a modified form (phytoevaporation), adsorption or precipitation of xenobiotics on the root surface collection and accumulation of impurities in root tissues (rhizofiltration), or stabilization (phytostabilization) of harmful compounds (Marecik et al., 2006; Grobelak et al., 2010; Posmyk and Urbaniak, 2014). Vegetation with the ability to purify soil contaminated with heavy metals in the presence of petroleum substances appears to have enormous potential that can be used on a wide scale to restore utility value of contaminated areas in the long term (Atagana, 2011; Gałązka and Gałązka, 2016; Kluk and Steliga, 2016). However, to achieve this objective, an attempt should be made to select available vegetation on the basis of tests carried out in laboratory conditions.

The characteristics of quantitative and qualitative composition of contaminants does not fully reflect their harmfulness in relation to living organisms. Toxicological studies in which morphological changes of bioindicators are observed in contact with xenobiotics and their metabolites provide an objective assessment on the degree of threat the contaminated soils may be subjected to. Bioassays usually use bacteria, invertebrates and embryophyta as the main groups of organisms (MankiewiczBoczek et al., 2008; Baran and Tarnawski, 2013; Baudo et al., 2015; Jakubus and Tatuśko, 2015). For fast, repeatable and reliable bacterial tests, the microbiological risk assessment test MARA should be employed. On the other hand, tests which use invertebrates and embryophyta as bioindicators include tests of the type of ToxKit (Phytotoxkit ${ }^{\mathrm{TM}}$, Spirodela Duckweed Toxkit, Ostracodtoxkit $\mathrm{F}^{\mathrm{TM}}$ ). Bioassays have the advantage of being able to determine the amount of the pollutant that causes acute or chronic toxicity, which in turn allows the estimation on the effects of organisms exposure to a given substance (Gabrielson et al., 2003; Sekutowski and Bartniak, 2009; Fai and Grant, 2010; Zima, 2012; Foucault et al., 2013; Jakubowicz et al., 2013; Oleszczuk et al., 2014; Niyommaneerat et al., 2017; Steliga et al., 2018).

\section{Research material}

The experimental study was done on contaminated soils with $\mathrm{Pb}, \mathrm{Zn}, \mathrm{TPH}$ in the following variants:

- Total Petroleum Substances (TPH) and Polycyclic Aromatic Hydrocarbons (PAH) in quantities of $[5 \mathrm{~g}$ TPH $+20 \mathrm{mg}$ naphthalene (Nap) $+20 \mathrm{mg}$ phenanthrene $(\mathrm{Phe})+20 \mathrm{mg}$ fluoranthene (Flt) + $7.5 \mathrm{mg}$ chrysene(Chr)]/kg d.m. - Soil A; - heavy metals: $\mathrm{Pb}$ and $\mathrm{Zn}$ at concentration of $(500 \mathrm{mg} \mathrm{Pb}$ + 1000 mg Zn) $/ \mathrm{kg}$ d.m. - Soil B;

- petroleum substances (TPH - petroleum fractions with a boiling point $>260^{\circ} \mathrm{C}$ ), PAH and heavy metals in quantities $(5 \mathrm{~g} \mathrm{TPH}+20 \mathrm{mg} \mathrm{Nap}+20 \mathrm{mg}$ Phe $+20 \mathrm{mg}$ Flt + $7.5 \mathrm{mg} \mathrm{Chr}+500 \mathrm{mg} \mathrm{Pb}+1000 \mathrm{mg} \mathrm{Zn)/kg} \mathrm{d.m.} \mathrm{-} \mathrm{Soil} \mathrm{C.}$

Helianthus annuus was used as a phytoremediant. The results were presented in milligrams per kilogram of sample dry mass (mg/kg d.m.).

\section{Research methodology}

The implementation of the work assumptions required the physical and chemical tests on soil samples with different 
contamination levels. The following contaminants were determined in the tested soils: content of metals from heavy metals group $(\mathrm{Pb}, \mathrm{Zn})$, biogenic components and quantity of petroleum substances TPH and PAH (Nap, Phe, Flt, Chr).

In the collected soil samples, moisture was determined by the gravimetric method with heat, based on the sample mass loss when submitted to $105^{\circ} \mathrm{C}$. In order to determine the remaining components, the soil was brought to an air-dry state by being conditioned at ambient conditions for 7 days. The air dry soil was sieved through a $1 \mathrm{~mm}$ sieve and then analyzed.

Isolation of the described analytes from the soil matrix was made by:

- TPH extraction from the soil with support of dichloromethane as a solvent in a Soxhlet apparatus, concentration of the extract and purification on a SPE column filled with Florisil;

- PAHs extraction from soil with petroleum ether as a solvent in Soxhlet apparatus, then selective separation of PAHs on the $\mathrm{CN} / \mathrm{SiOH}$ refill of SPE columns, elution of PAHs from the ledge with the solvents: acetone : toluene $=3: 1$;

- making an aquatic extract of soil with soil to water ratio of $1: 10(\mathrm{~m}: \mathrm{m})$;

- soil mineralization in concentrated $\mathrm{HNO}_{3}$ solution in Ertec's made microwave digestion system Mangum II.

TPH extracted with dichloromethane were determined by the weight method after evaporation of the solvent. Gas chromatography was used to measure the content of PAH; the GC parameters are shown in Table 1.

The aqueous soil extract was analyzed to determine the following parameters: $\mathrm{pH}$, humidity and cation content: $\mathrm{K}^{+}$, $\mathrm{NH}_{4}{ }^{+}$and anions: $\mathrm{F}^{-}, \mathrm{Cl}^{-}, \mathrm{NO}_{3}{ }^{-}, \mathrm{PO}_{4}{ }^{3-}, \mathrm{SO}_{4}{ }^{2-}$. Soil components isolated by mineralization were analyzed to measure the content of heavy metals $(\mathrm{Pb}, \mathrm{Zn})$ as well as calcium and magnesium. The $\mathrm{pH}$ of the soils aqueous solutions was determined by potentiometric method, whereas the anions and cations were determined by a suitable chromatographic method using the Sycam ion chromatograph. The chromatograph was configured by connecting proper combinations of columns and detectors before starting every new analytical method.

After adjusting the content of biogenic components to the optimal values with the use of the ,Azofoska" mineral fertilizer on the soil collected from an agricultural crop area it was used to prepare samples of soils contaminated with known concentrations of: heavy metal salts, petroleum substances TPH and PAH, soil samples contaminated with known doses of heavy metal salts as well as petroleum substances TPH and PAH. The content of biogenic components in the soil were selected based on phytotoxicity test results. Photo 1 shows the plants grown on soil subjected to Phytotoxkit ${ }^{\mathrm{TM}}$ test plates.

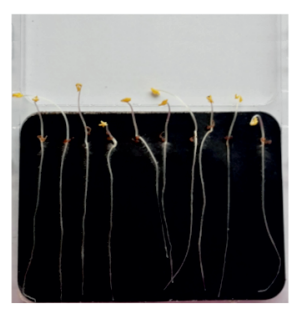

Lepidium sativum

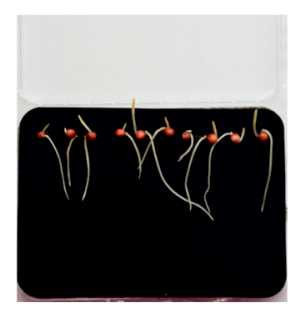

Sorghum saccharatum

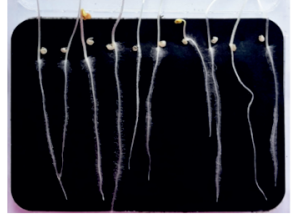

Sinapis alba
Photo 1. Phytotoxkit ${ }^{\mathrm{TM}}$ test plates picturing the growth of plants tested on soil with configured content of biogenic components

Fot. 1. Płytki testu Phytotoxkit ${ }^{\mathrm{TM}}$ ze wzrostem testowanych roślin na glebie o skorygowanych zawartościach składników biogennych

Characteristics of the soil used in the experiment were: $\mathrm{pH}_{(1 \% \mathrm{KCl})}$ of 7.1 , humidity of $26.8 \%$, ТPH $-162 \mathrm{mg} / \mathrm{kg} \mathrm{d.m.,}$ lead $-21.1 \mathrm{mg} / \mathrm{kg}$ d.m., zinc $-61.8 \mathrm{mg} / \mathrm{kg}$ d.m., calcium - $514 \mathrm{mg} / \mathrm{kg}$ d.m., magnesium - $126 \mathrm{mg} / \mathrm{kg}$ d.m., potassium - $25 \mathrm{mg} / \mathrm{kg}$ d.m., nitrogen - $105 \mathrm{mg} / \mathrm{kg}$ d.m., phosphorus $-33 \mathrm{mg} / \mathrm{kg}$ d.m.

The next stage of research was creation of Helianthus annuus pot plantation with set pollutant values. The experiment was executed under ex-situ condition with the use of four pot trial series. The first series consisted of contaminated soils reference sample (soils: A, B and C) and soil without addition of impurities

Table. 1. Parameters of the chromatographic method for the determination of PAHs on the Clarus 600 GC gas chromatograph

Tabela 1. Parametry chromatograficznej metody oznaczania WWA na chromatografie gazowym Clarus 600 GC

\begin{tabular}{|c|c|c|c|c|c|}
\hline \multicolumn{5}{|c|}{ Parameter of the chromatograph } & \multirow[b]{3}{*}{ Calibration standards } \\
\hline & & Temperature $\left[{ }^{\circ} \mathrm{C}\right]$ & \multirow[b]{2}{*}{ 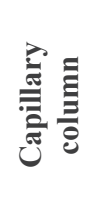 } & \multirow{2}{*}{ שֶ } & \\
\hline 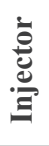 & 芯 & Temperature program & & & \\
\hline $\begin{array}{l}\text { Oे } \\
\stackrel{\text { }}{\text { ñ }}\end{array}$ & 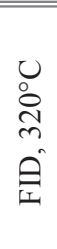 & $\begin{array}{l}40^{\circ} \mathrm{C} \text { - constant temperature } 2 \mathrm{~min} \\
40-240^{\circ} \mathrm{C} \text { - temp. increase rate } 30^{\circ} \mathrm{C} \mathrm{min}{ }^{-1} \\
240-320^{\circ} \mathrm{C} \text { - temp. increase rate } 8^{\circ} \mathrm{C} \mathrm{min}{ }^{-1} \\
320^{\circ} \mathrm{C} \text { - constant temperature } 10 \mathrm{~min}\end{array}$ & 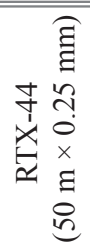 & 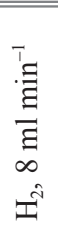 & $\begin{array}{c}\text { Reference soil containing } 16 \text { PAHs: } \\
\text { BAM - ERM-CC013 } \\
\text { Mixture of } 16 \text { PAHs in chloroform: } \\
\text { No } 31011\left(2000 \mu \mathrm{g} \mathrm{ml}^{-1} \text { each) }\right. \\
\text { No } 31264\left(500-1000 \mu \mathrm{g} \mathrm{ml}^{-1}\right) \\
\text { No } 31451\left(100-200 \mu \mathrm{g} \mathrm{ml}^{-1}\right) \text { made by Restek }\end{array}$ \\
\hline
\end{tabular}


on which no plants were planted. The next series included trials with Helianthus annuus. During six-month experiment the conditions of plants growth were maintained by proper hydration.

The assessment on the effectiveness of phytoremediation treatments used in the soil purification process in addition to the determination of the toxicant concentration, was based on the results of toxicological tests in the initial phase of the experiment and after its completion. Soil samples were analyzed using five microbiotests with organisms belonging to trophic levels of: producers (Phytotoxkit ${ }^{\mathrm{TM}}$ and Spirodela Duckweed Toxkit), consumers (Ostracodtoxkit ${ }^{\mathrm{TM}}$ ) and decomposers (MARA). Toxicological tests were executed according to producers instructions in three repetitions - on uncontaminated soil and the soil used in phytoremediation process (soil contaminated with the known dosage of $\mathrm{Pb}$ and $\mathrm{Zn}$ ions, and petroleum substances TPH and PAH).

\section{Methodology of toxicological tests}

Phytotoxkit chronic toxicity test is based on the assessment of germination and early plant growth. Three types of plants are used in the test, those plants are selected based on germination and root growth swiftness which enables complete marking in the span of three-day incubation: Sorghum bicolor (Sorghum saccharatum), garden cress (Lepidium sativum), white mustard (Sinapis alba). Research is conducted in polystyrene transparent test plates.

Incubation conditions: temperature, $T=25^{\circ} \mathrm{C}$ in darkness, incubation time, $t=72 \mathrm{~h}$.

Test reaction: germination and early root growth suppression.

Microbiotest assessing the Spirodela Duckweed Toxkit toxicity is a suppression test of (or lack of it) aquatic embryophyta Spirodela polyrhiza growth. This test allows for evaluating the suppression of growth of germinating turions after three days of exposure to toxic substances in relation to the reference which is carried out in non-toxic medium. Plant growth is determined by measuring the surface of the first leaves at times $t=0 \mathrm{~h}$ and $t=72 \mathrm{~h}$ using an image analysis program. Based on the results a calculation for plant growth suppression is made (72h-EC 50).

The tests are carried out in a 48-well microplate at 5 concentrations of the tested toxicant, each in 8 repetitions. The research material were water extracts of soils. The criterion for considering the test as valid was the value of the average growth of the first leaflets in the row of reference wells after 3 days of incubation at $25^{\circ} \mathrm{C}$ and under 6000 lux illumination ( $=\mathrm{t} 72 \mathrm{~h}-\mathrm{t} 0 \mathrm{~h}$ area values) higher or equal to $10 \mathrm{~mm}^{2}$.

Chronic toxicity test Ostracodtoxkit $\mathbf{F}^{\mathrm{TM}}$ is performed using young crustaceans Heterocypris incongruens hatched from endospore cysts within 52 hours. After 6 days of contact with the tested sediment, their mortality rate percentage and growth suppression are determined in relation to the results obtained in contact with a non-toxic reference sediment. The test is performed on 6-well microplates $(3 \times 2)$, incubation time: 6 days at $25^{\circ} \mathrm{C}$.

Microtox ${ }^{\circledR} /$ DeltaTox - the acute toxicity test is based on the fluorescence measurement of the Vibrio fischeri bacteria which normally consume about $10 \%$ of the metabolism for light production. In the electron transport system of these bacteria, the enzyme luciferase (alkane oxygenase) catalyzes the oxidation of the reduced substrate (reduced flavin mononucleotide, riboflavin mononucleotide or flavin-adenine dinucleotide), and luminescence signal generated during this process is measured by a photometer. The created substrates involved in this reaction are oxygen and a long chain aldehyde. In the presence of substances that negatively affect cellular metabolism, bacteria react very quickly by decreasing the luminescence which is measured using Delta Tox analyzer after 15 minutes of contact with the sample.

MARA Microbial Assay for Risk Assessment - an innovative environmental risk assessment test in which ten prokaryotic organisms are used as evaluation for chronic toxicity of samples that are used as bioindicators - bacteria belonging to different taxa and one eukaryote - yeast. The strains that were used in the MARA microbiological test: Microbacterium spaciec, Brevundimonas diminuta, Citrobacter freudii, Comamonas testosteroni, Entrococcus casseliflavus, Delftia acidovorans, Kurthia gibsoni, Staphylococcus warneri, Pseudomonas aurantiaca, Serriatia rudidaea, Pichia anomala.

Freeze-dried bioindicators are placed by the manufacturer in a 96-well microplate made with polystyrene which is then hermetically packed under sterile conditions. In the MARA test, the toxicity of the sample is assessed based on the growth suppression degree of test organisms after 18 hours of incubation. The observed visual effect is a water-insoluble red dye, secreted by healthy bacteria eat nutrient solution with addition of tetrazolium medium. After the test is completed, the plate is scanned and its image analyzed by a special image analysis program. The resultant data is evaluated as:

- Minimum MTC value - concentration that is toxic to the most sensitive organism;

- Maximum MTC value - concentration that is toxic to the least sensitive organism;

- Average MTC value - the average concentration value that is toxic to all organisms;

- Information about toxic action of a substance (fingerprint) - a unique toxic concentrations table of a given substance (sample) for individual test organisms which can be compared with tables marked for other substances. 


\section{Research results report}

Contaminated soil samples were prepared for research (Soil A, Soil B, Soil C) and subjected to physical and chemical analysis to determine levels of components implemented into the soil. As a result of the conducted research the recovery of individual pollutants was found at the level of:

Soil A: TPH - 93.4\%, PAH - 92.2\% (Nap - 95.2\%,

Phe $-94.2 \%$, Flt $-90.4 \%$, Chr $-87.7 \%$ );

Soil B: $\mathrm{Zn}-97.0 \%, \mathrm{~Pb}-94.0 \%$;

Soil C: TPH - 93.1\%, PAH - 91.9\% (Nap - 95.1\%,

Phe $-94.1 \%$, Flt $-90.1 \%$, Chr $-86.8 \%$ ),

$\mathrm{Zn}-95.0 \%, \mathrm{~Pb}-90.6 \%$.

The 6-month phytoremediation of polluted soils caused a decrease in the content of pollutants in the studied soils, which was confirmed by physical, chemical and toxicological tests of the treated soils. On the basis of the conducted experiment, it should be noted that soils containing insignificant content of heavy metals resulting from their natural occurrence during the vegetation of Helianthus annuиs phytoremediant decreased very slightly (Soil A). In contrast, soils contaminated with heavy metals at higher concentration (Soil B) or mixtures of heavy metals and petroleum substances TPH and PAH (Soil C) have undergone significant purification (Fig. 1). Those soils had the following reduced values of:

- lead: from $495 \mathrm{mg} / \mathrm{kg} \mathrm{d} . \mathrm{m}$. to $226 \mathrm{mg} / \mathrm{kg}$ d.m. for soil B, from $472 \mathrm{mg} / \mathrm{kg}$ d.m. to $318 \mathrm{mg} / \mathrm{kg}$ d.m. for soil C and - zinc: from $1030 \mathrm{mg} / \mathrm{kg} \mathrm{d} . \mathrm{m}$. to $520 \mathrm{mg} / \mathrm{kg} \mathrm{d.m}$. for soil B, from $998 \mathrm{mg} / \mathrm{kg}$ d.m. to $656 \mathrm{mg} / \mathrm{kg}$ d.m. for soil C.

The next analyzed aspect of the phytoremediation process was the possibility of using phytoremediation to decrease content of petroleum substances with particular emphasis on polycyclic aromatic hydrocarbons in soils. The soil used to make samples of contaminated soil (Soil A, Soil B, Soil C) contained $162 \mathrm{mg} \mathrm{TPH} / \mathrm{kg}$ d.m. and $0.14 \mathrm{mg} \mathrm{PAH} / \mathrm{kg}$ d.m. After six-month experiment in uncontaminated soil left as „control soil” the content of TPH decreased from 162 to $158 \mathrm{mg} / \mathrm{kg} \mathrm{d.m}$. In the soil which was used for the growth of Helianthus annuиs, after the experiment a higher ТРН loss (145 mg/kg d.m.) was noted. Similar effect was spotted for PAH whose content in contaminated soil decreased to a low level (Nap - $0.06 \mathrm{mg} / \mathrm{kg}$ d.m., Phe $-0.02 \mathrm{mg} / \mathrm{kg}$ d.m., Flt $-0.01 \mathrm{mg} / \mathrm{kg}$ d.m., $\mathrm{Chr}-0.05 \mathrm{mg} / \mathrm{kg}$ d.m.).

Six-month long phytoremediation process of soil initially contaminated with petroleum substances TPH and PAH (soil A) led to their significant reduction, specifically of the following components:

- $2774 \mathrm{mg} \mathrm{TPH} / \mathrm{kg}$ d.m. which means a decrease by $42.5 \%$, and for control soil by $14.0 \%$;

- $13.36 \mathrm{mg} \mathrm{Nap} / \mathrm{kg}$ d.m. which means a decrease by $30.0 \%$, and for control soil by $4.5 \%$;

- $13.76 \mathrm{mg}$ Phe/kg d.m. which means a decrease by $27.0 \%$ and for control soil by $3.9 \%$;

- $13.28 \mathrm{mg}$ Flt $/ \mathrm{kg}$ d.m. which means a decrease by $26.5 \%$ and for control soil by $3.0 \%$;

- $5.33 \mathrm{mg} \mathrm{Chr} / \mathrm{kg}$ d.m. which means a decrease by $19.5 \%$ and for control soil by $1.1 \%$.

On the other hand after six months of phytoremediation the soil contaminated with both heavy metals and petroleum substances TPH and PAH (Soil C) was shown to have the values organic components decreased to:

- $3180 \mathrm{mg} \mathrm{TPH} / \mathrm{kg}$ d.m. which means a decrease by $33.8 \%$ and for control soil by $11.5 \%$,

- $13.74 \mathrm{mg} \mathrm{Nap} / \mathrm{kg}$ d.m. which means a decrease by $27.9 \%$ and for control soil by $4.0 \%$,

- $14.14 \mathrm{mg}$ Phe/kg d.m. which means a decrease by $24.9 \%$ and for control soil by $3.7 \%$,

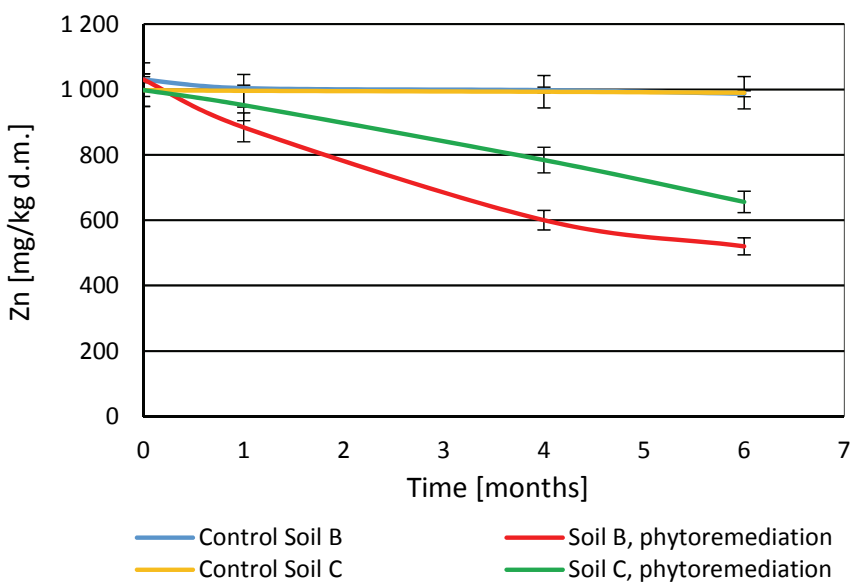

Fig. 1. Influence of time on phytoremediation process using Helianthus annuus on the effect of cleaning soil contaminated with heavy metals (Soil B) and heavy metals, TPH and PAH (Soil C)

Rys. 1. Wpływ czasu prowadzenia procesu fitoremediacji z wykorzystaniem Helianthus annuus na efekt oczyszczania gleby zanieczyszczonej metalami ciężkimi (Gleba B) oraz metalami ciężkimi, TPH i WWA (Gleba C) 
- $\quad 13.74 \mathrm{mg}$ Flt/kg d.m. which means a decrease by $23.8 \%$ and for control soil by $2.2 \%$,

- $5.66 \mathrm{mg} \mathrm{Chr} / \mathrm{kg}$ d.m. which means a decrease by $13.6 \%$ and for control soil by $0.3 \%$.

High content of heavy metals $(\mathrm{Pb}, \mathrm{Zn})$ generally implied a slowdown in the reduction of petroleum substances (TPH and $\mathrm{PAH}$ ) in the soil.

\section{Toxicological tests}

During 72-hours Phytotoxkit ${ }^{\mathrm{TM}}$ test the decrease (or the absence) of germination and early growth of garden cress (Lepidium Sativum), sorghum (Sorghum saccharatum), white mustard (Sinapis alba) on contaminated soils was measured compared to germination and growth in the reference soil. The results of the conducted research were related to the results obtained for grain growth on the reference soil (provided by the manufacturer of the Phytotoxkit ${ }^{\mathrm{TM}}$ test). The test showed that in the soil that was used to prepare soil samples with a known degree of pollution and soil provided by the manufacturer of the Phytotoxkit ${ }^{\mathrm{TM}}$ test, all grain species got germinated in $100 \%$. The test for contaminated soils showed that in the soil containing TPH and PAH (Soil A), Lepidium Sativum and Sinapis alba seeds germinated at 100\%, while Sorghum saccharatum seeds at $90 \%$. In soil contaminated with heavy metals (Soil B), Sinapis alba seeds germinated at 100\%, Lepidium Sativum at $90 \%$, and Sorghum saccharatum at $80 \%$. The lowest germination resistance for tested seeds was characterized by soil contaminated with both TPH and PAH and heavy metals (Soil C), ranging from Sinapis alba (90\%) to Sorghum saccharatum $(70 \%)$.

In the case of soil contamination with petroleum substances TPH and PAH, the tested plants, in the experimentally conducted phytoremediation process, had difficult access to the uptake of water and mineral salts from the substrate; in addition, there was a disruption of root ventilation, which resulted in significant suppression in the growth of both the root and shoot systems.

After phytoremediation of contaminated soils, the level of germinated seeds increased to $80-100 \%$. The second measured parameter which was the inhibition root growth on the tested plants in contaminated soils, before and after the six-month phytoremediation period compared to their growth in the reference soil, showed a significant reduction in inhibition growth of the purified soils:

- Soil A from 20.5-61.8\% to $18.0-23.0 \%$;

- $\quad$ Soil B from $48.9-81.2 \%$ to $21.6-31.8 \%$;

- $\quad$ Soil C from $44.5-56.0 \%$ to $18.4-38.5 \%$.

Effectiveness of phytoremediation processes of contaminated soil are presented in Figure 2.

The effect of the phytoremediation process on contaminated soil was also evaluated on the basis of Spirodela Duckweed Toxkit microbiotest which indicates the growth suppression of aquatic embryophyta Spirodela polyrhiza after 72 hours of exposure to toxic substances in relation to the reference sample in non-toxic medium. The study was carried out for aqueous extracts of the studied soils which were obtained as a result of the daily contact with water at a ratio of 1:10 m:m. Based on the test results presented in Table 2, the effectiveness of the phytoremediation process has been demonstrated. This is evidenced by the higher 72-EC 50 values (effective concentration causing 50-percent leaf growth suppression) calculated for phytoremediated soil aqueous extracts compared to the soil before the purification process. An increase was noted regarding the values of: 72-EC 50: from 70.5 to the lack of soil toxicity (Soil A), from 35.4 to 64.1 (Soil B) and from 30.8 to 79.7 (Soil C).

For the soil toxicity tests used in phytoremediation processes (uncontaminated and with the addition of pollutants), the trophic level representatives of consumers namely Heterocypris incongruens, were used as biomarker. Those crustaceans were used
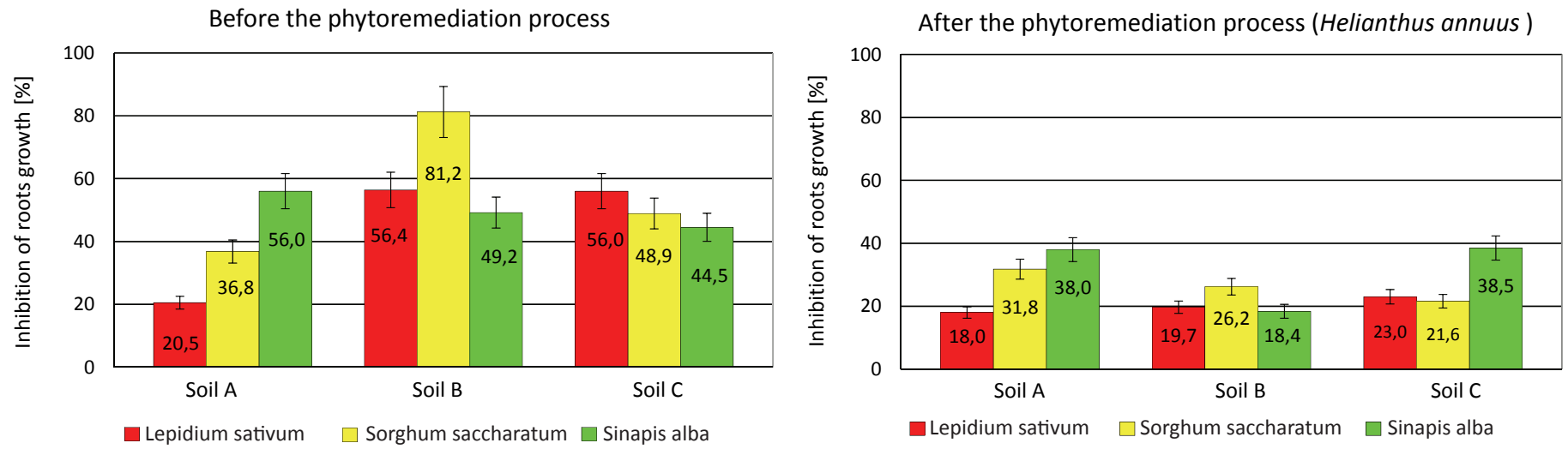

Fig. 2. Effectiveness of phytoremediation process on contaminated soil according to phytotoxicity tests made before and after phytoremediation

Rys. 2. Efekt procesu fitoremediacji skażonej gleby według testów fitotoksyczności wykonanych przed i po procesie fitoremediacji 
Table 2. Toxicology test results sheet: Spirodela Duckweed Toxkit, Ostracodtoxkit $\mathrm{F}^{\mathrm{TM}}$ and MARA before and after phytoremediation process Tabela 2. Zestawienie wyników testów toksykologicznych: Spirodela Duckweed Toxkit, Ostracodtoxkit $\mathrm{F}^{\mathrm{TM}}$ oraz MARA przed i po procesie fitoremediacji

\begin{tabular}{|c|c|c|c|c|c|c|c|}
\hline \multirow{3}{*}{ Parameter } & \multicolumn{7}{|c|}{ Type of soil used in phytoremediation process } \\
\hline & \multicolumn{4}{|c|}{ before phytoremediation } & \multicolumn{3}{|c|}{ after phytoremediation } \\
\hline & referential & $\mathbf{A}$ & B & $\mathrm{C}$ & $\mathbf{A}$ & B & $\mathrm{C}$ \\
\hline \multicolumn{8}{|c|}{ Spirodela Duckweed Toxkit test } \\
\hline $72 \mathrm{~h}-\mathrm{EC} 50$ & 1.t." & $70,5 \pm 5$ & $35,4 \pm 3$ & $30,8 \pm 2$ & 1.t. ${ }^{*}$ & $64,1 \pm 5$ & $79,7 \pm 6$ \\
\hline \multicolumn{8}{|l|}{ Ostracodtoxkit $\mathrm{F}^{\mathrm{TM}}$ test } \\
\hline Average mortality [\%] & 3,3 & 43,3 & 86,7 & 95,0 & 23,3 & 33,3 & 40,0 \\
\hline Average org. length $[\mu \mathrm{m}]$ & $960 \pm 50$ & $480 \pm 20$ & $200 \pm 10$ & $167 \pm 10$ & $610 \pm 30$ & $570 \pm 25$ & $500 \pm 20$ \\
\hline Average org. growth [\%] & $780 \pm 30$ & $285 \pm 15$ & $\mathrm{X}$ & $\mathrm{X}$ & $480 \pm 20$ & $420 \pm 15$ & $380 \pm 10$ \\
\hline Growth inhibition [\%] & - & $63,5 \pm 5,0$ & $\mathrm{X}$ & $\mathrm{X}$ & $37,7 \pm 5,0$ & $45,5 \pm 5,0$ & $50,6 \pm 5,0$ \\
\hline \multicolumn{8}{|c|}{ Microtox ${ }^{\circledR S P T}$ test } \\
\hline Luminescence inhibition [\%] & $13 \pm 2$ & $36 \pm 3$ & $68 \pm 5$ & $73 \pm 5$ & $24 \pm 2$ & $44 \pm 4$ & $49 \pm 4$ \\
\hline EC $50[\%]$ & $\mathrm{N}$ & $\mathrm{N}$ & $19,2 \pm 2$ & $17,2 \pm 2$ & $\mathrm{~N}$ & $\mathrm{~N}$ & $\mathrm{~N}$ \\
\hline $\mathrm{TU}$ & - & - & 5,2 & 5,8 & - & - & - \\
\hline \multicolumn{8}{|c|}{ MARA test } \\
\hline $\operatorname{MTC}_{\min }\left[\%_{\text {vol. }}\right]$ & 80 & 65 & 32 & 36 & 74 & 66 & 59 \\
\hline $\mathrm{MTC}_{\max }\left[\% \%_{\mathrm{vol}}\right]$ & 100 & 96 & 91 & 65 & 100 & 98 & 85 \\
\hline MTC [\% $\left.\%_{\text {vol. }}\right]$ & 95 & 85 & 50 & 46 & 92 & 74 & 70 \\
\hline
\end{tabular}

${ }^{*} 1 . t$ - lack of toxicity

in the Ostracodtoxikit $\mathrm{F}^{\mathrm{TM}}$ test used to assess chronic toxicity, determined on the basis of mortality and growth suppression of test organisms after a six-day contact with the environmental factor. The test results were presented in table 2. Due to the mortality of biomarkers in contact with soil B and C exceeding $50 \%$ of the survival rate, the reduction in growth numbers of Heterocypris incongruens according to the recommended test procedure was not taken into account. Conducting the process of phytoremediation on contaminated soils caused a decrease in their toxicity. This is evidenced by the decrease in mortality and the average suppression of growth on the tested organisms, specifically:

- for Soil A a decrease in organisms mortality rate from $43.3 \%$ to $23.3 \%$ and decrease in average growth inhibition of Ostracods from 63.5 to $37.7 \%$;

- for Soil B a decrease in organisms mortality rate from $86.7 \%$ to $33.3 \%$ and decrease in average growth inhibition of Ostracods from undetermined to $45.5 \%$;

- for Soil $\mathrm{C}$ a decrease in organisms mortality rate from $95.0 \%$ to $40.0 \%$ and decrease in average growth inhibition of Ostracods from undetermined to $50.6 \%$.

To study the soil toxicity at the trophic level of decomposers, the Microtox ${ }^{\circledR}$ SPT microbiological solid phase assay with the use of luminescent bacteria Vibrio fischeri was applied. As a result of direct contact with the tested soil sample these bacteria experience a change in their metabolism as well as the capability of luminescence, which is a test reaction. Measurement of luminescence change of the $V$. fischeri in a nontoxic medium regarding the test sample makes it possible to determine the inhibition of luminescence. The Microtox ${ }^{\circledR}$ SPT test was performed according to the manufacturer's standard procedure (SDI) using the Delta TOX analyzer and freeze-dried bacteria. The results were calculated using the manufacturer's program giving the EC 50 value which is the concentration of the test sample causing a rise to $50 \%$ of the test response. The toxicity value is expressed as toxicity units (TU).

In the initial stage the screening tests were carried out for each type of soil, determining samples with a significant toxic effect, i.e. when the level of luminescence reduction of $V$. fischeri was higher than $50 \%$. In the next stage of research for soils characterized by a significant inhibition effect $(>50 \%)$ of V. fischeri, basic tests with dilutions were made to determine the EC 50 values needed to calculate the toxicity units (TU). The test results are summarized in Table 2.

The six-month phytoremediation process was carried out using a Helianthus annuus as the phytoremediant. Soil contaminated with particular toxicants reduced the level of pollutants to a level that caused the Microtox ${ }^{\circledR} S P T$ test to significantly reduce the inhibition of $V$. fischeri luminescence depending on the type of soil contamination, namely: 
- inhibition was reduced from $36 \%$ to $24 \%$ for Soil A;

- inhibition was reduced from $68 \%$ to $44 \%$ for Soil B;

- inhibition was reduced from $73 \%$ to $49 \%$ for Soil C.

Study results presented in Table 2 show the purification effect of all soil types by phytoremediation using Helianthus annuus as a phytoremediant. It can be clearly seen that the contact of $V$. fischeri with extracts of treated soils inhibited luminescence $<50 \%$, thus making it impossible to calculate the EC 50. These results prove that the purified soils were not toxic.

The assessment on effectiveness of the soil phytoremediation process was also based on MARA test results. The toxic concentrations of the tested soil extracts were evaluated for the most sensitive test organism $\left(\mathrm{MTC}_{\text {min. }}\right)$, for the most resistant test organism $\left(\mathrm{MTC}_{\text {max. }}\right)$ and the average toxic concentration value for all tested microorganisms (MTC - Micriobial Toxic Concentration). The research was done before and after the phytoremediation process.

Based on the results it should be noted that in the MARA test the reference soil used to prepare contaminated soils was non-toxic (MTC $=95 \%$ ). The organism number 11 was the most sensitive for this soil for which it resulted in $\mathrm{MTC}_{\text {min. }}=80 \%$. However, in the case of contaminated soils, the effect of their treatment was dependent on the type of pollution. Six-month long phytoremediation process of contaminated soils caused a significant degree of purification, as evidenced by the increase in average toxic concentrations (MTC) for MARA microorganisms under the conditions of the test, namely:

- for soil contaminated with petroleum substances (TPH and $\mathrm{PAH}$ ), as a result of phytoremediation a MTC increase from $85 \%$ to $92 \%$ was noted;

- for soil contaminated with heavy metals, as a result of phytoremediation a MTC increase from $50 \%$ to $74 \%$ was noted;

- for soil contaminated with heavy metals and petroleum substances (TPH and PAH), as a result of phytoremediation a MTC increase from $46 \%$ to $70 \%$ was noted.

The results of conducted experiment show that applying phytoremediation process led to contamination degree reduction to the level not posing any threat to the environment. When the process of phytoremediation of contaminated soils came to an end, the plant material was collected. Then it was turned into dry matter and mineralized, and the content of lead and zinc was determined. The results of the tests carried out are illustrated in Figure 3.
The data presented in Figure 3 shows that the extent of heavy metals accumulation in Helianthus annuus biomass depends on their concentration in the soil, which is the basis for plant growth. The graph shows that higher concentrations of heavy metals in soils correlated with an increase in their content in plants. In addition, based on the study of plant material, lower accumulation of lead can be observed compared to the accumulation of zinc.

\section{Summary}

1. The conducted research indicates the legitimacy of using combined research methods, including chemical analyses and ecotoxicological tests in assessing the effectiveness of phytoremediation processes in contaminated soils.

2. During six-month long research soil samples were monitored with a special attention paid to their toxicities, content of metals: $\mathrm{Pb}, \mathrm{Zn}$, and petroleum substances (TPH and $\mathrm{PAH}$ ). Then, the tested soil variants were used for toxicological research: Phytotoxkit ${ }^{\mathrm{TM}}$, Spirodela Duckweed Toxkit, Ostracodtoxkit $\mathrm{F}^{\mathrm{TM}}$, Microtox ${ }^{\circledR S P T}$ and microbiological risk assessment test MARA.

3. The process of phytoremediation of contaminated soils carried out for six months using the Helianthus annuus as a phytoremediant caused a significant reduction of the pollutant load in soils. This is confirmed both by the analyses performed on the chemical composition of soils and the toxicological tests carried out at the beginning of the experiment and after its completion.

This paper was written on the basis of the statutory work entitled: Variability of toxicity of rhizosphere of soil contaminated with TPH and heavy metals in phytoremediation processes - the work of the Oil and Gas Institute - National Research Institute was commissioned by the Ministry of Science and Higher Education; order number: 0003/KE, archival number: KE-4101-0003/18. 


\section{Literature}

Atagana H.I., 2011. Bioremediation of Co-contamination of Crude Oil and Heavy Metals in Soil by Phytoremediation Using Chromolaena odorata (L) King \& H.E. Robinson. Water, Air, \& Soil Pollution, 215 (1-4): 261-271. DOI: 10.1007/s11270-010-0476-z.

Baran A., Tarnawski M., 2013. Phytotoxkit/Phytotestkit and Microtox ${ }^{\circledR}$ as tools for toxicity assessment of sediments. Ecotoxicology and Environmental Safety, 98: 19-27. DOI: 10.1016/j.ecoenv.2013.10.010.

Baudo R., Foudoulakis M., Arapis G., Perdaen K., Lanneau W., Paxinou A.-C.M., Kouvdou S., Persoone G., 2015. History and sensitivity comparison of the Spirodela polyrhiza microbiotest and Lemna toxicity tests. Knowledge and Management of Aquatic Ecosystems, 416, 23: 1-16. DOI: 10.1051/kmae/2015019.

Bielińska E.J., Futa B., Ukalska-Jaruga A., Weber J., Chmielewski Sz., Wesołowska S., Mocek-Płóciniak A., Patkowski K., Mielnik L., 2018. Mutual relations between PAHs derived from atmospheric deposition, enzymatic activity, and humic substances in soils of differently urbanized areas. Journal of Soils and Sediments, 18: 2682-2691. DOI: 10.1007/s11368-018-1937-z.

Doni S., Macci C, Peruzzi E, Arenella M, Ceccanti B, Masciandaro G., 2012. In situ phytoremediation of a soil historically contaminated by metals, hydrocarbons and polychlorobiphenyls. Journal of Environmental Monitoring, 14: 1383-1390. DOI: 10.1039/ c2em11016d.

Fai P.B., Grant A., 2010. An assessment of the potential of the microbial assay for risk assessment (MARA) for ecotoxicological testing. Ecotoxicology, 19: 1626-1633. DOI: 10.1007/s10646-010-0548-2.

Foucault Y., Durand M.J., Tack K., Schreck E., Geret F., Leveque T., Pradère P., Goix S., Dumat C., 2013. Use of ecotoxicity test and ecoscores to improve the management of polluted soils: case of a secondary lead smelter plant. Journal of Hazardous Materials, 246-247:291-9. DOI: 10.1016/j.jhazmat.2012.12.042.

Gabrielson J., Kühn I., Colque-Navarro P., Hart M., Iversen A., McKenzie D., Möllby R., 2003. Microplate-based microbial assay for risk assessment and (eco)toxic fingerprinting of chemicals. Analytica Chimica Acta, 485(1): 121-130, DOI:10.1016/ S0003-2670(03)00404-5.

Gałązka A., Gałązka R., 2016. Phytoremediation of chemically contaminated soils. [In:] Kropiwiec K., Szala M. (eds.) Microbiology and analytical methods in science (In Polish). Wyd. Naukowe TYGIEL sp. z o.o.: 71-84.

Grobelak A., Kasprzak M., Fijałkowski K., 2010. Phytoremediation - the underestimated potential of plants in cleaning up the environment (In Polish). Journal of Ecology and Health. 14, 6: 276-280.

Jacob J.M., Karthik Ch., Saratale R.G., Kumar S.S., Prabakar D., Kadirvelu K. Pugazhendhi A., 2018. Biological approaches to tackle heavy metal pollution: A survey of literature. Journal of Environmental Management, 217: 56-70. DOI: 10.1016/j. jenvman.2018.03.077.

Jakubowicz P., Steliga T., Kluk D., 2013. Estimation of severe toxicity alternations in deposit waters using ecotoxicological tests (In Polish). Nafta-Gaz, 5: 409-417.

Jakubus M.B., Tatuśko N., 2015. Review of selected biological methods of assessing the quality of natural environment. Inżynieria Ekologiczna, 42: 78-86. DOI: 10.12912/23920629/1989.

Kacprzak M.J., Rosikon K., Fijalkowski K., Grobelak A., 2014. The Effect of trichoderma on heavy metal mobility and uptake by Miscanthus giganteus, Salix sp., Phalaris arundinacea, and Panicum virgatum. Applied and Environmental Soil Science, ID 506142: 1-10. DOI: 10.1155/2014/506142.
Khoramnejadian S., Khoramnejadian S., 2013. Phytoremediation of Heavy Metals and Total Petroleum Hydrocarbons by Amaranth. Journal of Biology and Today's World, 2 (12): 514-516.

Kluk D. Steliga T., 2016. An effective method for the identification of total petroleum hydrocarbons (TPH) and polycyclic aromatic hydrocarbons (PAHs) in soils (In Polish). Nafta-Gaz, 4: 230-241. DOI: 10.18668/NG.2016.04.02.

Mankiewicz-Boczek J., Nałęcz-Jawecki G., Drobniewska A., Kaza M., Sumorok B., Izydorczyk K., Zalewski M., Sawicki J., 2008. Application of a microbiotests battery for complete toxicity assessment of rivers. Ecotoxicology and Environmental Safety, 71 (3): 830-836. DOI: 10.1016/j.ecoenv.2008.02.023.

Marecik R., Króliczak P., Cyplik P., 2006. Phytoremediation - and alternative for traditional methods of environmental cleaning (In Polish). Biotechnologia, 3 (74), 88-97.

Niyommaneerat W., Nakajima F., Tobino T., Yamamoto K., 2017. Development of a chronic sediment toxicity test using the benthic ostracod Heterocypris incongruens and their application to toxicity assessments of urban road dust. Ecotoxicology and Environmental Safety, 143: 266-274. DOI: 10.1016/j.ecoenv.2017.05.011.

Oleszczuk P., Jośko I., Kuśmierz M., Futa B., Wielgosz E., Ligęza S., Pranagal J., 2014. Microbiological, biochemical and ecotoxicological evaluation of soils in the area of biochar production in relation to polycyclic aromatic hydrocarbon content. Geoderma, 213: 502-511. DOI: 10.1016/j.geoderma.2013.08.027.

Posmyk K., Urbaniak M., 2014. Phytoremediation as a biological method of environmental cleaning (In Polish). Aura, 7, 10-12.

Sekutowski T., Bartniak M., 2009. Usage of microbiotest phytotoxkit in detecting of allelopathic potential of phalaris arundinacea (In Polish). Journal of Research and Applications in Agricultural Engineering, 54 (4): 88-93.

Steliga T., Jakubowicz, P., Wojtowicz K., Kluk D., 2018. Application of toxicological tests in oil industry (In Polish). Nafta-Gaz, 9: 684-689. DOI: 10.18668/NG.2018.09.07.

Steliga T., Kluk D., 2017. Assessment of the composition of pollutionof soil contaminated with TPH and PAHs for the development of the bioremediation technology (In Polish). Prace Naukowe $I N i G-P I B, 215: 1-211$.

Zima G., 2012. The use of the bioindication method to evaluate the toxicity of chemicals used in the composition of drilling fluids (In Polish). Nafta-Gaz, 2: 115-122.

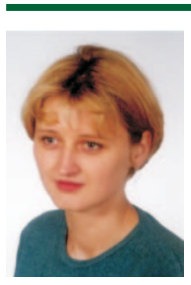

Dorota KLUK Ph.D. Eng.

Assistant Professor, Department of Reservoir Fluid Production Technology

Oil and Gas Institute - National Research Institute 25 A Lubicz St.

31-503 Krakow

E-mail:dorota.kluk@inig.pl

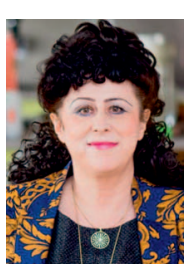

Teresa STELIGA Ph.D. Eng.

D.Sc. Associate Professor, Department of Reservoir Fluid Production Technology

Oil and Gas Institute - National Research Institute

25 A Lubicz St.

31-503 Krakow

E-mail: teresa.steliga@inig.pl 